\title{
Simultaneous Inhibition of SARS-CoV-2 Infectivity by a Specific Combination of Plant-derived Compounds
}

\author{
Anna Goc, Vadim Ivanov, Svetlana Ivanova, Madhurima Chatterjee, Matthias Rath, \\ and Aleksandra Niedzwiecki
}

\section{ABSTRACT}

\begin{abstract}
SARS-CoV-2 pandemic remains a challenge to human health and economy worldwide. Previously we have shown that a combination of active plantderived compounds and plant extracts can dose-dependently inhibit binding of RBD-spike protein SARS-CoV-2 to the ACE2 receptor and its expression on human alveolar epithelial cells. Here we use eGFP-luciferase-SARS-CoV2 spike protein pseudo-virions and SARS-CoV-2-RdRp, to show if the antiviral effectiveness of this combination of plant-derived compounds and plant extracts expands to other important key mechanisms of SARS-CoV-2 infection. Or results revealed that this combination of five plant-derived compounds inhibited the attachment of the SARS-CoV-2 pseudo-typed particles with lung hACE2/A549 cells. In addition, it down-regulated the activity of key enzymes known to be crucial for the entry of the SARS-CoV2 virus, such as TMPRSS2, furin and cathepsin $L$, but not their expression at protein level. This combination did not affect ACE2 binding to and ACE2 enzymatic activity, but modestly decrease cellular expression of neuropilin1 molecule and significantly inhibited activity of viral RdRp. This study demonstrates inhibitory effects of this combination on key cellular mechanisms of SARS-CoV-2 infection. The findings further support the use of plant-derived compounds as effective health measures against SARSCoV-2-caused infection.
\end{abstract}

Keywords: ACE2, cathepsin L, furin, NPR-1, SARS-CoV-2, TMPRSS2.
Published Online: September 12, 2021 ISSN: $2684-5199$

DOI: $10.24018 /$ ejbio.2021.2.5.258

A. Goc

Dr. Rath Research Institute, 5941 Optical Ct., San Jose, CA 95138, USA.

(e-mail:a.goc@drrath.com)

V. Ivanov

Dr. Rath Research Institute, 5941 Optical Ct., San Jose, CA 95138, USA.

(e-mail: v.ivanov@drrath.com)

S. Ivanova

Dr. Rath Research Institute, 5941 Optical

Ct., San Jose, CA 95138, USA.

(e-mail: s.ivanova@drrath.com)

M. Chatterjee

Dr. Rath Research Institute, 5941 Optical

Ct., San Jose, CA 95138, USA

(e-mail: m.chatterjee@drrath.com)

M. Rath

Dr. Rath Research Institute, 5941 Optical

Ct., San Jose, CA 95138, USA.

(e-mail: m.rath@drrath.com)

A. Niedzwiecki*

Dr. Rath Research Institute, 5941 Optical

Ct., San Jose, CA 95138, USA.

(e-mail: author@drrath.com)

*Corresponding Author

\section{INTRODUCTION}

Despite numerous and drastic public health measures, the spread of COVID-19 is still not effectively controlled, which further threatens global health and economies of the world [1]. According to WHO, as of November 2020, there have been over 55 million COVID-19 cases worldwide, resulting in more than 1,300,000 deaths [2].

Sequencing the whole genome and identification of the mechanism by which SARS-CoV-2 infects the host cells created a necessary scientific foundation to concentrate the global efforts of the scientific and medical community on developing effective preventive and therapeutic measures against coronaviruses [3], [4].

Initial step of the SARS-CoV-2 infectivity, i.e., viral attachment through receptor-binding domain (RBD) on its $\mathrm{S} 1$ subunit with the host angiotensin-converting enzyme 2 (hACE2) receptor, a membrane protein abundantly expressed in type II alveolar cells, seems to be detrimental [5], [6]. Consequently, it is also a major target for the development of vaccines and therapeutics [7], [8]. Recently, Daly et al. have demonstrated that neuropilin-1 (NRP-1), profusely present on the respiratory and nasal epithelial cells, also serves as host receptor for SARS-CoV-2 virus [9]. They established that the furin-cleaved S1 fragment of the spike protein attaches directly to NRP-1 and were successful in reducing viral infection in vitro with a small-molecule inhibitor or monoclonal antibodies. Moreover, Cantuti-Castelvetri et al. [10] further showed that this molecule beside ACE2 receptor facilitates SARS-CoV-2 passing through the cellular membrane and is involved in SARS-CoV-2 infectivity process.

It has been shown that for viral attachment to the receptor, fusion, and viral endocytosis the "priming" of coronaviruses' (CoVs) spike proteins by protease cleavage is also required [11]. Recent studies identified that the "priming" of spike protein of SARS-CoV-2 occurs through a sequential two-step protease cleavage, i.e., between $\mathrm{S} 1$ and $\mathrm{S} 2$ sub-units, and on the S2 sub-unit itself [12] with participation if several host proteases in this process [3], [6], [13]. The majority of studies on SARS-CoV-2 imply critical participation of transmembrane protease serine-2 (TMPRSS2) and cathepsin 
$\mathrm{L}$ as these defining viral binding and cellular entry [14]. However, involvement of other proteases accompanying SARS-CoV-2 entry, such as furin, cannot be discounted.

Since SARS-CoV-2 is a RNA virus, it requires its RNAdependent RNA polymerase (RdRp) to mediate the replication and transcription of its viral genome [15]. Indeed, one of the main functions of the $R d R p$ is to synthesize negative-sense genomic RNA from positive-sense genomic RNA, and to replicate the viral genome. Its active site is the most conserved region within RNA viruses; thus, this region is considered as a prime candidate for targeting the viral replication through the development of effective antiviral therapeutics.

The global human intellectual and economic resources concentrated on the search for interventional drugs and vaccines to curb and control COVID-19 have not yet brought satisfactory results. Moreover, these potential treatments are surrounded by public concerns about risks of adverse side effects that might be overlooked or might have yet to surface with a "fast track" implementation of new vaccines or drugs.

At the same time, we cannot ignore the plethora of scientific data showing the antiviral efficacy of numerous naturally derived compounds that can be applied as safe and effective measures against COVID-19. Already, at early stages of this pandemic, high doses of ascorbic acid (vitamin C) administrated intravenously have been used as a therapy with promising results. Clinical benefits of intravenous ascorbic acid, for example, have been confirmed in a latest study led in critically ill COVID-19 patients [16]. Potential applications of other nutrients and active plant components have also been considered and evaluated in various studies, with the majority of these evaluations limited to individual compounds, based on molecular modelling data or theoretical extrapolations of known efficacy of these compounds in other infections or pathologies [17]-[19].

Our research strategy with regards to SARS-CoV-2 involved a comprehensive approach, by simultaneously targeting mechanisms of the early steps of the viral infection with specifically selected natural compounds. Natural substances appear superior in this approach as all micronutrients have a high margin of safety, and, by taking part in numerous metabolic pathways, they can affect various cellular mechanisms at once. In our earlier studies we identified two micronutrient compositions with a noticeable anti-SARS-CoV-2 efficacy. A definite combination of ascorbic acid, certain minerals, amino acids and plant extracts showed to significantly decrease ACE2 expression on main types of cells targeted by SARS-CoV-2, i.e., human lung alveolar epithelial cells (SAEC) and human lung endothelial cells [20]. Another combination of polyphenols and plant extract was effective in blocking attachment of the RBD of SARS-CoV-2 with the hACE2, reducing at the same time the expression of the ACE2 receptor in SAEC [21].

Here we, we further investigated the anti-SARS-CoV-2 potential of the latter combination of polyphenols and plant extract PB (as stated in Experimental Procedures section B (Plant-derived composition). Here we demonstrate that this combination in our PB composition could inhibit SARSCoV-2 pseudo-typed particles binding to human lung cells overexpressing the ACE2 receptor. PB showed concentration-dependent efficacy when applied either 1 hour before or simultaneously with exposing the pseudo-virus to ACE2 overexpressing human lung A549 epithelial cells. Its anti-binding efficacy persisted also when PB was added 1 hour after the cellular introduction of pseudo-virions.

Additionally, we showed for the first time that $\mathrm{PB}$ is effective in inhibiting the activity of TMPRSS2, cathepsin L and furin, all of which were shown to enable the binding and internalization of SARS-CoV-2. Moreover, PB could significantly inhibit the activity of $\mathrm{RdRp}$, interestingly however, we observed that $\mathrm{PB}$ did not bind to or affect enzymatic activity of ACE2 directly.

\section{EXPERIMENTAL PROCEDURES}

\section{A. Cell Cultures, Constructs, Pseudo-typed Virions, and Antibodies}

A549 cell line was from American Type Culture Collection (Manassas, VA). hACE2/A549 cells (i.e., A549 cells stably overexpressing human ACE2 receptor) and eGFP-luciferaseSARS-CoV-2 spike protein encapsulated pseudo-typed particles were from GenScript (Piscataway, NJ). Pseudotyped $\Delta \mathrm{G}$-luciferase $\left(\mathrm{G}^{*} \Delta \mathrm{G}\right.$-luciferase) $\mathrm{rVSV}$ was obtained from Kerafast (Boston, MA). Bald eGFP-luciferase-SARSCoV-2 pseudo-typed particles were from BPS Bioscience (San Diego, CA). Lentiviral particles carrying human TMPRSS2 were from Addgene (Watertown, MA). All antibodies were from R\&D Systems (Minneapolis, MN) if not specified otherwise.

\section{B. Plant-derived Composition}

The combination tested in this study consisted of $400 \mathrm{mg}$ of quercetin, $400 \mathrm{mg}$ of cruciferous plant extract, $300 \mathrm{mg}$ of turmeric root extract, $300 \mathrm{mg}$ of green tea extract $(80 \%$ polyphenols) and $50 \mathrm{mg}$ of resveratrol. A stock solution of this plant-derived combination was prepared in DMSO at 100 $\mathrm{mg} / \mathrm{ml}$ and kept at $-20{ }^{\circ} \mathrm{C}$ until analysis. For the experiments, the stock solution was diluted with 1 x PBS (enzyme activity assays) or corresponding cell culture medium (cell expression assays) to final concentrations indicated in the figures.

\section{Binding of SARS-CoV-2 Pseudo-typed Virions to hACE2 Receptor}

The experiment was executed according to GenScript recommendations with small modifications. Briefly, eGFPluciferase-SARS-CoV-2 spike protein encapsulated pseudovirions were incubated at $37{ }^{\circ} \mathrm{C}$ with $0-100 \mu \mathrm{g} / \mathrm{ml}$ of $\mathrm{PB}$ for 1 hour before it was either added into a monolayer of hACE2/A549 cells, simultaneously added to hACE2/A549 cells, or was added to the cells after 1 hour post-treatment. A parallel experiment was performed in which eGFPluciferase-CoV-2 spike protein pseudo-virions were spininoculated at $1,250 \times \mathrm{g}$ for 1.5 hours. Cells were incubated for an additional 1 hour, 3 hours and 48 hours, at $37^{\circ} \mathrm{C}$. After the 1-hour and 3-hour incubation periods, cells were washed three times with washing buffer, and primary antibody against SARS-CoV-2 spike protein at 1:1000 dilution, followed by HRP-conjugated secondary antibody at 1:2500 dilution, were employed in ELISA assay. After the 48-hour incubation period (with or without spinfection), the transduction efficiency was quantified by recording of the luciferase activity, utilizing a luciferase assay system 
(Promega, Madison, WI) and a spectrofluorometer (Tecan Group Ltd., Switzerland). Positive and negative controls used in 1-hour and 3-hour experiments, were provided by the manufacturer. In the 48-hour experiments, the positive control was bald eGFP-luciferase-SARS-CoV-2 pseudotyped particles, and the negative control was $\Delta \mathrm{G}$-luciferase rVSV pseudo-typed particles. Data are presented as a $\%$ of control without PB addition (mean $+/-\mathrm{SD}, \mathrm{n}=6$ ).

\section{TMPRSS2 Activity Assay and Its Cellular Expression}

\section{1) TMPRSS2 Activity}

TMPRSS2 activity assay in cell-based assay was performed according to previous report [22]. Briefly, A549 cells overexpressing TMPRSS2 were treated with PB at 5.0 and $10 \mu \mathrm{g} / \mathrm{ml}$ concentrations 48 hours or 3 hours prior to the enzymatic activity assessment. Cells were then washed with growth medium (without added phenol red), and the activity was initiated by addition of the $200 \mu \mathrm{M}$ fluorogenic substrate Mes-D-Arg-Pro-Arg-AMC for 30 minutes at $37{ }^{\circ} \mathrm{C}$ (Fisher Scientific, Pittsburgh, PA), using a spectrofluorometer at extension/emission $=360 / 440 \mathrm{~nm}$ (Tecan Group Ltd., Switzerland). The positive control was $50 \mu \mathrm{M}$ camostat mesylate. Data are presented as a \% of control without PB addition (mean $+/-\mathrm{SD}, \mathrm{n}=6$ ).

Effect of $\mathrm{PB}$ on the activity of isolated TMPRSS2 protease, $1 \mu \mathrm{M}$ fluorogenic peptide Boc-Gln-Ala-Arg-AMC was added to the $\mathrm{PB}$ diluted at 5.0 and $10 \mu \mathrm{g} / \mathrm{ml}$ concentrations followed by supplementation with $10 \mu \mathrm{M}$ of TMPRSS2 (Creative BioMart, Shirley, NY) for 1 hour at RT. Fluorescence was assessed using a spectrofluorometer at extension/emission=360/440 nm (Tecan Group Ltd., Switzerland). The positive control was $100 \mu \mathrm{M}$ camostat mesylate. Data are presented as a $\%$ of control without PB addition (mean $+/-\mathrm{SD}, \mathrm{n}=6$ ).

\section{2) TMPRSS2 expression}

Expression of TMPRSS2 in cells was performed using Human TMPRSS2 ELISA Kit (Novus Biologicals, Centennial, CO). Briefly, 48 hours prior to the analysis, A549 cells were treated with PB at 5.0 and $10 \mu \mathrm{g} / \mathrm{ml}$ concentrations. Next, all wells were washed with $1 \mathrm{x}$ PBS and lysed with CellLytic M buffer (MilliporeSigma, St. Louis, MO). Lysates were then processed according to procedure described in the ELISA manual provided by the manufacturer.

\section{E. Cathepsin L Activity Assay and Its Cellular Expression}

\section{1) Cathepsin L activity}

Experiment was performed in cell lysates using a Cathepsin L Activity Assay Kit (Abcam, Cambridge, MA) according to the manufacturer's protocol. Briefly, $5 \times 106$ A549 cells treated with $\mathrm{PB}$ at 5.0 and $10 \mu \mathrm{g} / \mathrm{ml}$ concentrations for 24 hours were washed with cold $1 \times$ PBS and lysed $100 \mu 1$ with CL buffer for 8 minutes. After 3 minutes of centrifuged for at $4{ }^{\circ} \mathrm{C}$, supernatants were collected and enzymatic reaction was set up by mixing $50 \mu \mathrm{l}$ of treated sample, $50 \mu \mathrm{l}$ of control sample, $50 \mu \mathrm{l}$ of background control sample, $50 \mu \mathrm{l}$ of positive and negative controls. $50 \mu \mathrm{l} \mathrm{CL}$ buffer and $1 \mu \mathrm{l} 1$ mM DTT was added next followed by addition of $2 \mu \mathrm{l}$ of 10 $\mathrm{mM}$ CL substrate Ac-FR-AFC except for the background control. Samples were incubated at $37{ }^{\circ} \mathrm{C}$ for 1 hour, and fluorescence was recorded at extension/emission $=400 / 505$ $\mathrm{nm}$ with a fluorescence spectrometer (Tecan Group Ltd.,
Switzerland). Data are presented as a $\%$ of control without PB addition (mean $+/-\mathrm{SD}, \mathrm{n}=6$ ).

Effect of PB on the activity of isolated cathepsin L, a Cathepsin L Activity Screening Assay Kit (BPS Bioscience, San Diego, CA) was used according to the manufacturer's protocol. Briefly, $\mathrm{PB}$ at 5.0 and $10 \mu \mathrm{g} / \mathrm{ml}$ concentrations was added to cathepsin $\mathrm{L}(0.2 \mathrm{mU} / \mu \mathrm{l})$ for 15 minutes at $22{ }^{\circ} \mathrm{C}$ prior to fluorogenic substrate (Ac-FR-AFC) $(10 \mu \mathrm{M})$ addition and incubation for 60 minutes at RT. Positive control contained only cathepsin L, and negative control containing cathepsin $\mathrm{L}$ and cathepsin $\mathrm{L}$ inhibitor E64d $(25 \mu \mathrm{M})$. The fluorescence was recorded at extension/emission $=360 / 480$ $\mathrm{nm}$ with a fluorescence spectrometer (Tecan Group Ltd., Switzerland). Data are presented as a percentage of control without $\mathrm{PB}$ addition (mean $+/-\mathrm{SD}, \mathrm{n}=6$ ).

\section{2) Cathepsin L expression}

Expression of cathepsin $\mathrm{L}$ in cells was performed using Western blot. Briefly, 48 hours prior to the analysis, A549 cells were treated with $\mathrm{PB}$ at 5.0, and $10 \mu \mathrm{g} / \mathrm{ml}$ concentrations. Next, cells were washed with 1 x PBS, lysed, and processed according to procedure described in paragraph $\mathrm{K}$ (Western Blot) below.

\section{F. Furin Activity and Its Cellular Expression}

\section{1) Furin Activity}

Effects of PB on furin enzymatic activity were evaluated using a SensoLyte Rh110 Furin Activity Assay Kit (AnaSpec, Fremont, CA) in accordance with the manufacturer's protocol. Briefly, PB at 5.0 and $10 \mu \mathrm{g} / \mathrm{ml}$ concentrations were mixed with furin recombinant protein for 15 minutes, followed by the addition of fluorogenic $\mathrm{Rh} 110$ furin substrate. The samples were incubated for 1 hour at $22{ }^{\circ} \mathrm{C}$ and the fluorescence was recorded at extension/emission $=490 / 520 \mathrm{~nm}$ with a fluorescence spectrometer (Perceptive Biosystems Cytofluor 4000). Data are presented as a $\%$ of control without $\mathrm{PB}$ addition (mean +/$\mathrm{SD}, \mathrm{n}=6$ ).

\section{2) Furin Expression}

Monolayers of A549 cells in 96-well plates were exposed to $\mathrm{PB}$ at 5.0 and $10 \mu \mathrm{g} / \mathrm{ml}$ concentrations for 48 hours. Cell layers were then washed with $1 \mathrm{x}$ PBS and fixed by incubation with $3 \%$ paraformaldehyde/ $0.5 \%$ Triton X-100 for 1 hour at $4 \mathrm{oC}$. After four washing cycles with $1 \mathrm{x}$ PBS, cell layers were treated overnight with $1 \%$ bovine serum albumin (Rockland, CA) in $1 \mathrm{x}$ PBS at 4oC. Furin expression was analyzed by immunochemical ELISA assay using rabbit polyclonal anti-human furin primary antibodies (1:5000 dilution) (Invitrogen, CA) and polyclonal secondary antibodies conjugated with HRP (1:5000 dilution) (Rockland, CA). Nonspecific antibody-binding values were determined as HRP retention in samples not exposed to specific primary antibodies. Specific antibody binding was determined after subtraction of averaged nonspecific binding values from total binding value. Data are presented as a \% of control without $\mathrm{PB}$ addition (mean $+/-\mathrm{SD}, \mathrm{n}=6$ ).

\section{G. hACE2 Activity and Binding Assays}

Effect of PB on the activity of isolated hACE2 protein was examined using ACE2 Activity Screening Assay Kit (BPS Bioscience, San Diego, CA) according to the manufacturer's 
protocol. Briefly, 5.0 and $10 \mu \mathrm{g} / \mathrm{ml}$ of PB were added to ACE2 protein $(200 \mathrm{mU} / \mathrm{ml})$ for 15 minutes at $22^{\circ} \mathrm{C}$, followed by addition of ACE2 fluorogenic substrate $(10 \mu \mathrm{M})$ and incubation for 1 hour at $22{ }^{\circ} \mathrm{C}$. The positive control contained only ACE2 enzyme, and the negative control additionally contained $10 \%$ DMSO. The fluorescence was recorded at extension/emission=535/595 $\mathrm{nm}$ using a fluorescence spectrometer (Tecan Group Ltd., Switzerland). Data are presented as a $\%$ of control without PB addition (mean +/$\mathrm{SD}, \mathrm{n}=6$ ).

Effect of $\mathrm{PB}$ on binding to the hACE2 receptor was examined using an ACE2 Inhibitor Screening Assay Kit (BPS Bioscience, San Diego, CA) according to the manufacturer's protocol. Briefly, plate with immobilized hACE2 receptors $(1.0 \mu \mathrm{g} / \mathrm{ml})$ were incubated with PB at 5.0 and10 $\mu \mathrm{g} / \mathrm{ml}$ concentrations for 1 hour at RT. The positive control contained 55\% DMSO. After incubation, the plate was washed three times with washing buffer, blocked with blocking buffer for 1 hour, and incubated with antibody against hACE2 at 1:500 dilution for 1 hour, subsequently being washed four times, blocked with blocking buffer, and incubated with HRP-conjugated secondary antibody at 1:1000 dilution also for 1 hour. The chemiluminescence was assessed using ECL reagent kit and fluorescence spectrometer (Tecan Group Ltd., Switzerland). Data are presented as a $\%$ of control without PB addition (mean $+/$ $\mathrm{SD}, \mathrm{n}=6)$.

\section{H. Neuropilin-1 Cellular Expression Assay}

Monolayers of A549 cells in 96-well plates were exposed to $\mathrm{PB}$ at $5.0,10$, and $20 \mu \mathrm{g} / \mathrm{ml}$ concentrations for 48 hours. Cell layers were then washed with $1 \mathrm{x}$ PBS and fixed by incubation with $3 \%$ paraformaldehyde in $\mathrm{PBS} / 0.5 \%$ Triton $\mathrm{X}-100$ for 1 hour at $4^{\circ} \mathrm{C}$. After four washing cycles with $1 \mathrm{x}$ PBS, cell layers were treated overnight with $1 \%$ bovine serum albumin (Rockland, CA) in $1 \mathrm{x}$ PBS at 4oC. NRP-1 expression was analyzed by immunochemical ELISA assay using rabbit polyclonal anti-human NPR-1 primary antibodies (1:5000 dilution) (Invitrogen, CA) and polyclonal secondary HRP-conjugated antibodies (1:5000 dilution) (Rockland, CA). Nonspecific antibody-binding values were determined as HRP retention in samples not exposed to specific primary antibodies. Specific antibody binding was determined after subtraction of averaged nonspecific binding values from total binding value. Data are expressed as a $\%$ of control without $\mathrm{PB}$ addition (mean $+/-\mathrm{SD}, \mathrm{n}=6$ ).

\section{In vitro RdRp Activity}

In vitro RdRp activity was examined using a SARS-CoV2 RNA Polymerase Assay Kit (ProFoldin, Hudson, MA) according to the manufacturer's protocol. Briefly, $0.5 \mu \mathrm{l}$ of 50 x recombinant RdRp was incubated with $2.5 \mu 1$ of $50 \mathrm{x}$ buffer and $21 \mu \mathrm{l}$ of PB at 5.0, 10, 25, and $100 \mu \mathrm{g} / \mathrm{ml}$ concentrations for 15 minutes at RT, followed by the addition of master mix containing $0.5 \mu \mathrm{l}$ of $50 \mathrm{x}$ NTPs and $0.5 \mu \mathrm{l}$ of $50 \mathrm{x}$ template (as a single-stranded polyribonucleotide). The reaction $(25 \mu \mathrm{l})$ was incubated for 2 hours at $34{ }^{\circ} \mathrm{C}$ and then stopped by addition of $65 \mu \mathrm{l}$ of $10 \mathrm{x}$ fluorescence dye, and the fluorescence signal was recorded within 10 minutes at extension/emission=488/535 $\mathrm{nm}$ using a fluorescence spectrometer (Tecan, Group Ltd., Switzerland). Positive control contained $100 \mu \mathrm{g} / \mathrm{ml}$ remdesivir. Results are expressed as a \% of control without PB addition (mean +/$\mathrm{SD}, \mathrm{n}=6)$.

\section{J. Viability}

Cell viability assay was performed using MTT substrate. Briefly, $40 \times 103$ A549 cells per well were treated with different concentrations of PB for up to 48 hours. Next, wells were washed with 1 x PBS and complete growth medium supplemented with $5 \mathrm{mg} / \mathrm{ml}$ MTT was added, followed by incubation for 4 hours at $37^{\circ} \mathrm{C}$. Next, the culture medium was aspirated and $100 \mu \mathrm{l}$ of methanol was added. The absorbance was assessed at $570 \mathrm{~nm}$ with fluorescence spectrometer (Molecular Devices, San Jose, CA). Data are presented as a $\%$ of control without $\mathrm{PB}$ addition (mean $+/-\mathrm{SD}, \mathrm{n}=6$ ).

\section{K. Western Blot}

A495 cells were lysed with lysis buffer [RIPA buffer plus $1 \mathrm{x}$ Protease Inhibitor (ThermoFisher Scientific, Waltham, MA)]. The protein estimation was performed with Dc Protein Assay (Bio-Rad, Hercules, CA). A $45 \mu \mathrm{g} /$ well of protein was separated on $8-16 \%$ gradient SDS-PAGE gels and transferred to a PVDF membrane. Detection was performed with antibodies against cathepsin $\mathrm{L}$ at 1:200 dilution (Santa Cruz Biotechnology, Santa Cruz, CA) and against $\beta$-actin at 1:1000 dilution (Cell Signaling, Danvers, MA).

\section{Statistical Analysis}

Data for all experiments are presented as an average value and standard deviation from at least three independent experiments. Comparison between different samples was done by a two-tailed T-test using the Microsoft Office Excel program. Differences between samples were considered significant at $\mathrm{p}$ values lesser than 0.05 .

\section{RESUlTS}

\section{A. Effect of $P B$ on Receptor Binding}

The effects of PB on attachment and entering of SARSCoV-2 spike-enveloped virions were tested using lung cells stably overexpressing human ACE2 receptor (i.e., A549/hACE2 cells). The results presented in Fig. 1 show the concentration-dependent inhibitory effects of $\mathrm{PB}$ on binding of the spike-encapsulated pseudo-virions to A549/hACE2 cells. PB was added to the pseudo-virions 1 hour before, simultaneously with the pseudo-virions, or 1 hour after A549/hACE2 cells were exposed to pseudo-virions. The resulting blockage of the virion binding was evaluated after 1 hour and 3 hours of exposure to the entire experimental mixture. The results show a concentration-dependent inhibition of viral binding to A549/hACE2 cells, with maximum inhibition obtained at $100 \mu \mathrm{g} / \mathrm{ml} \mathrm{PB}$ concentration. At this concentration, similar levels of binding inhibition were observed in all three patterns of PB administration: 1 hour before, simultaneously, and 1 hour after virion-cells interaction, and after 1 hour and 3 hours of exposure of cells to virions together with $\mathrm{PB}$.

The inhibitory effect on virion binding was more pronounced after 1 hour of exposure and equaled about $90 \%$ after factoring in positive control values (Fig. 1A). After 3 hours of exposure the maximum inhibitory effect achieved at $\mathrm{PB}$ concentration of $100 \mu \mathrm{g} / \mathrm{ml}$ was $55-60 \%$ (in relation to 
positive controls) and was basically similar for different $\mathrm{PB}$ exposure patterns (Fig. 1B). After 1 hour incubation period, $\mathrm{PB}$ at $10 \mu \mathrm{g} / \mathrm{ml}$ when added simultaneously with pseudovirions and A549 cells, inhibited the binding by $63 \%$, whereas $75 \%$ inhibition was observed when incubation time

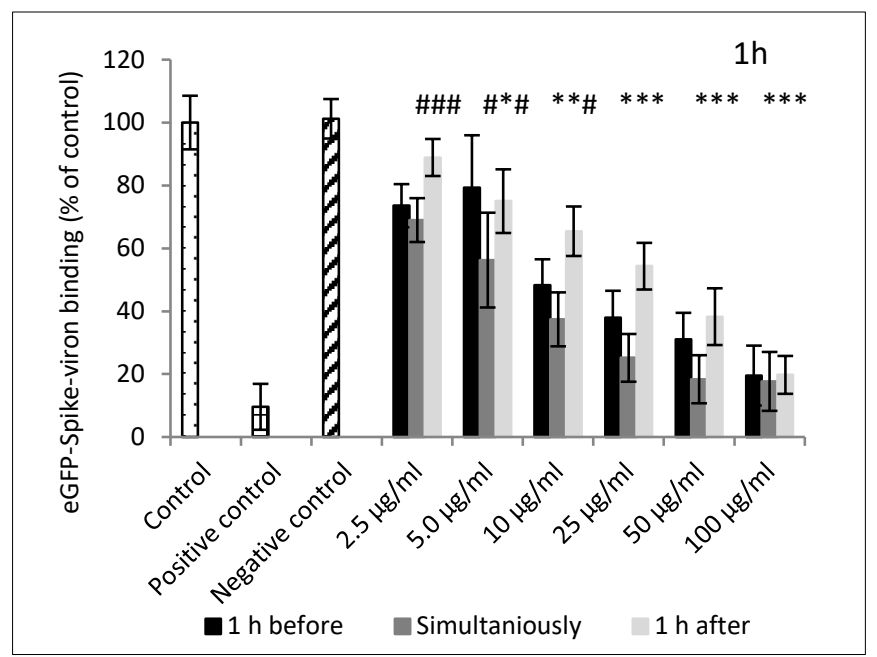

A was extended to 3 hours. The inhibition obtained with a dose of $25 \mu \mathrm{g} / \mathrm{ml}$ after 1 hour and 3 hours was similar and equaled $51 \%$ and $52 \%$, respectively, and observed at non-toxic concentrations (Fig. 1C).

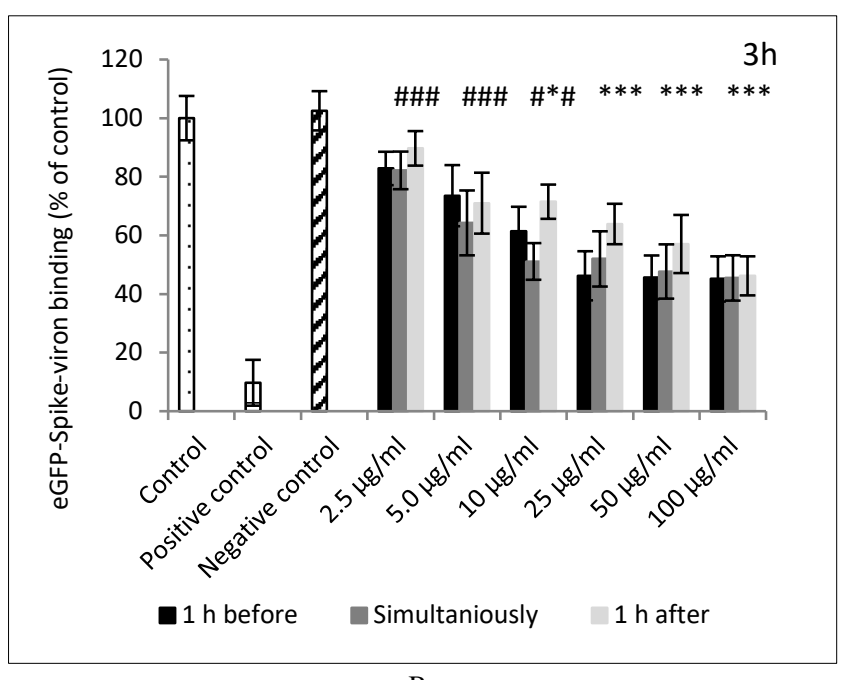

B

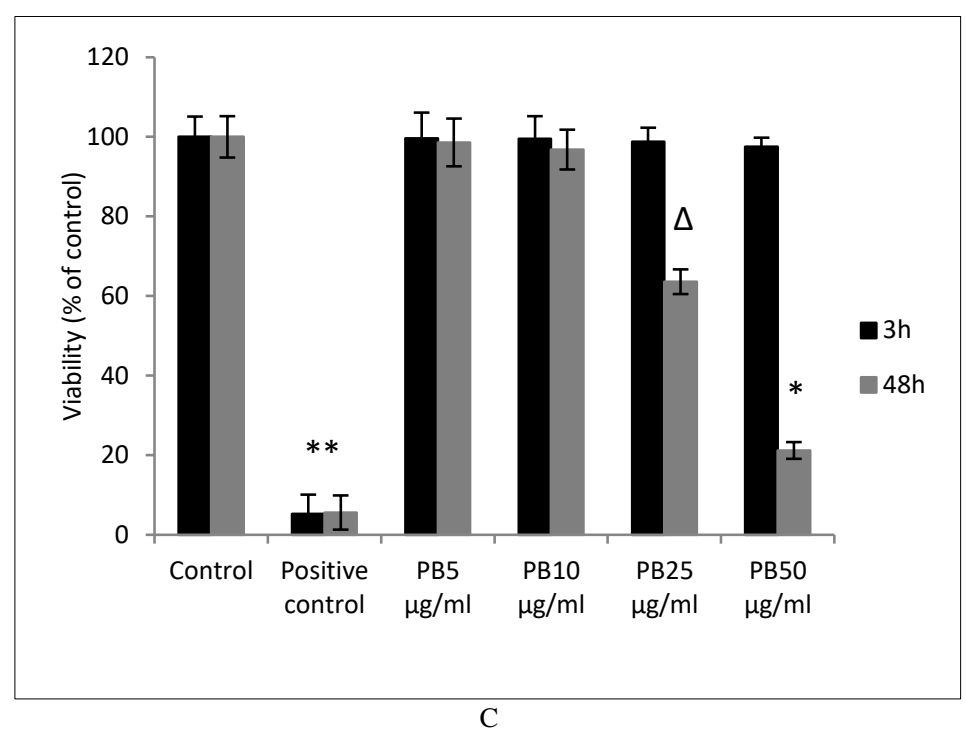

Fig. 1. Effects of PB on SARS-CoV-2 eGFP-luciferase pseudo-virions attachment to hACE2. Spike protein encapsulated pseudo-virions were treated with designated PB concentrations for $1 \mathrm{~h}$ prior to inoculation, added at once or $1 \mathrm{~h}$ after inoculation of the pseudo-typed particles into hACE2/A549 cells. After $1 \mathrm{~h}$ (A) or $3 \mathrm{~h}$ (B) of exposure attachment was assessed by utilizing primary antibody against spike protein followed by secondary HRP-conjugated antibody and signal measurement at $450 \mathrm{~nm}$. (C). Viability of A549 cells upon treatment with PB. Viability of cells was assessed using MTT method as described in Experimental Procedures section. Controls $-0.01 \%$ DMSO, positive and negative controls for A and B were provided by the manufacturer and for C $-100 \%$ dead cells; $\# \mathrm{p} \leq 0.05, \Delta \mathrm{p} \leq 0.01,{ }^{*} \mathrm{p} \leq 0.001$.

The effects of BP on the attachment and entry of pseudovirions encapsulated with eGFP-luciferase spike protein were examined with and without spinfection in A5 49/hACE2 cells (Fig. 2A and 2B). The results show that after 48 hours of incubation without spinfection there was a dose-dependent decrease in cell transduction by pseudo-virions by the PB. The differences in inhibitory effects between different application patterns were not statistically significant. Highest efficacy in binding inhibition was observed when virions were incubated for 1 hour with PB 'prior being added to the cells, compared with PB either simultaneous or 1-hour after addition with virions and cells. The results on Fig. 2B show that spinfection could facilitate the virions' binding, as the binding inhibition by corresponding PB concentrations was lower compared with non-spinfected cells. However, PB was still effective in causing about $20 \%$ binding inhibition at 10 $\mu \mathrm{g} / \mathrm{ml}$ PB concentrations, respectively. PB beyond $25 \mu \mathrm{g} / \mathrm{ml}$ concentrations affected cell morphology that might contribute to the inhibitory effects as shown in Fig. 1C. 


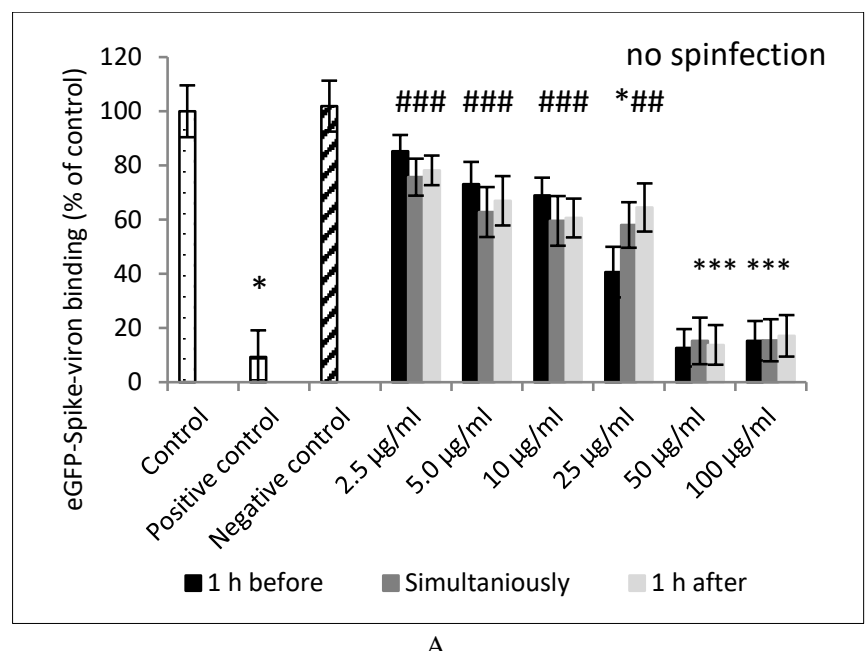

A

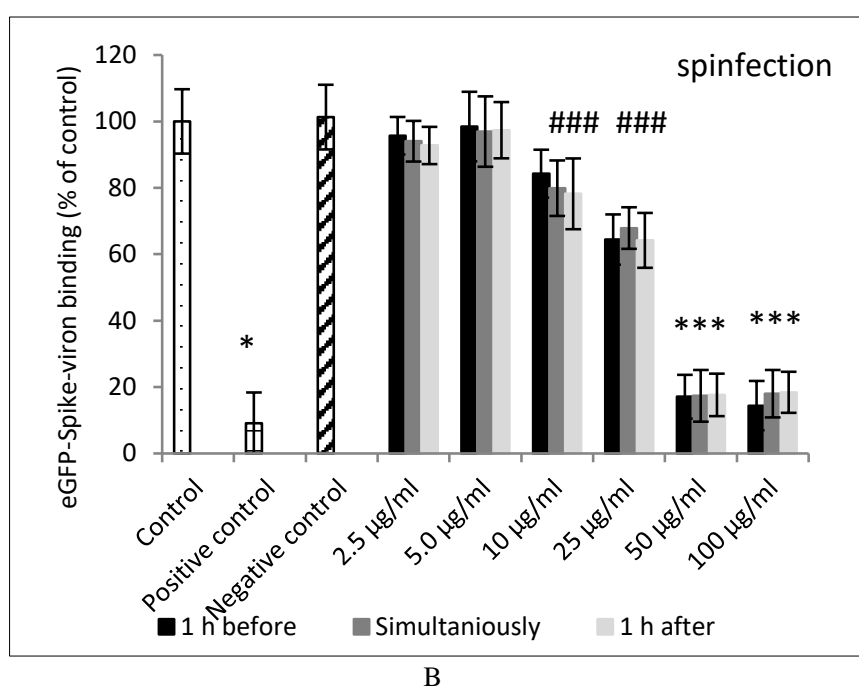

Fig. 2. Effect of PB on SARS-CoV-2 eGFP-luciferase pseudo-virions entry. hACE2/A549 cells were inoculated with spike protein encapsulated pseudovirions treated with designated $\mathrm{PB}$ concentrations and pattern of exposure without spinfection (A) and with spinefection (B). After $48 \mathrm{~h}$ postinoculation, transduction efficacy was assessed according to luciferase activity. Control - 0.01\% DMSO, positive control - bald SARS-CoV-2 eGFP-luciferase pseudo-virions, negative control $-\Delta$ G-luciferase rVSV pseudo-virions. \# $\mathrm{p} \leq 0.05, * \mathrm{p} \leq 0.001$.

\section{B. Effect of PB on Host Cellular Receptors and Proteases}

It was already demonstrated that SARS-CoV-2 must attach to the ACE2 if it is to enter the host cell. Our previous results showed that PB interferes with attachment of the RBD of spike protein to the ACE2 molecule by directly binding to RBD sequence [21]. The results in Fig. 3 show that PB did not bind to the ACE2 receptor or affect its activity as observed in free-cell assays. However, we observed dosedependent down-regulation of cellular expression of NPR-1, another receptor participating in SARS-CoV-2 cell entry and infectivity, showing the statistical significance at $20 \mu \mathrm{g} / \mathrm{ml}$ concentration (Fig. 3C).

Except host receptors, specific cell surface proteases are also required to facilitate SARS-CoV-2 cellular entry by "priming" spike protein by enzymatic cleavage. These include TMPRSS2, cathepsin L, and furin, all implicated in viral binding and internalization. In our study we employed cell-free and cell-based assays to study the effects of PB on activity of these enzymes. As presented in Fig. 4A and 4B, PB applied at $10 \mu \mathrm{g} / \mathrm{ml}$ showed statistically significant inhibition of TMPRSS2 activity in cell-free assay by about $31 \%$. This enzyme activity assessed in A549 cells also resulted in a $25 \%$ decrease in the presence of PB at $10 \mu \mathrm{g} / \mathrm{ml}$ concentration. This inhibition occurred in dose-dependent fashion and concurred with the concentrations that revealed to have inhibitory efficacy in viral binding. Interestingly, TPMRSS2 expression at protein level was not affected by PB at these concentrations (Fig. 4C).
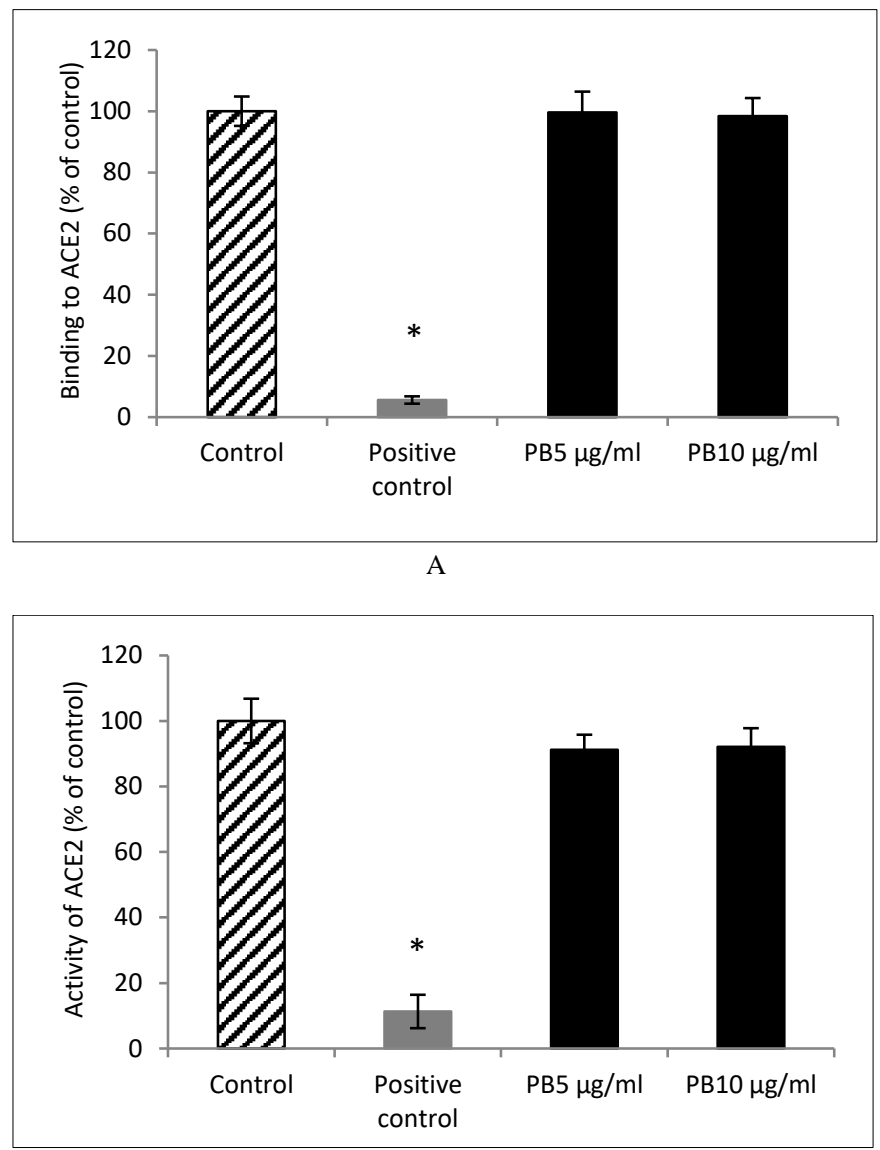

B

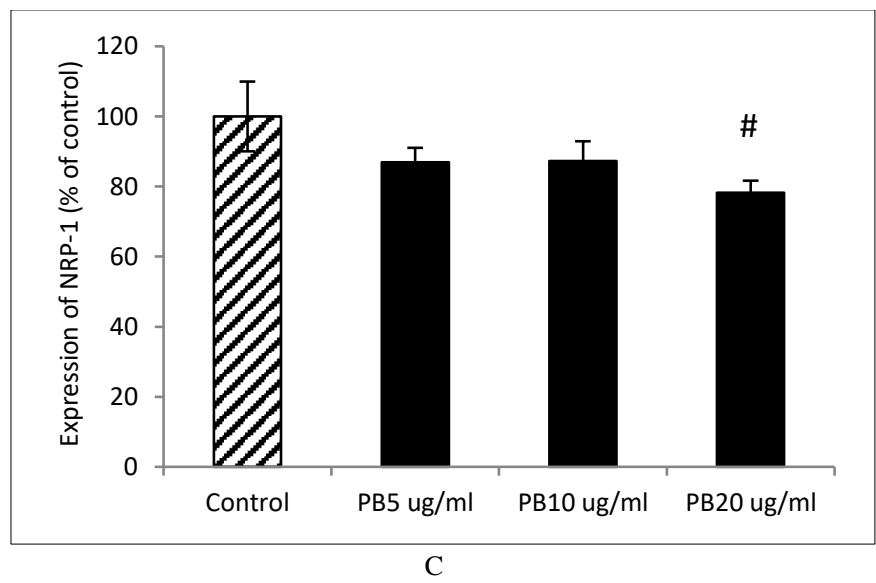

Fig. 3. Effect of PB on hACE2 and NRP-1 receptors. (A). Binding of PB at indicated concentration to hACE2 receptor immobilized on the plate using HRP-conjugated secondary antibody and measuring chemiluminescence signal. (B). Activity of hACE2 upon treatment with PB. $10 \mu \mathrm{M}$ of recombinant hACE2 was incubated with $\mathrm{PB}$ at indicated concentrations for $1 \mathrm{~h}$ at RT followed by the application of $1 \mu \mathrm{M}$ of fluorogenic substrate for 30 minutes. Fluorescence was recorded at extension/emission $=360 / 480 \mathrm{~nm}$ with spectrofluorometer. (C). Expression of NRP-1 in A549 cells after $48 \mathrm{~h}$ treatment with indicated concentrations of $\mathrm{PB}$ assayed by ELISA as described in Experimental procedures section. Control - 0.01\% DMSO, positive control $-50 \%$ DMSO; \# $\mathrm{p} \leq 0.05$. 


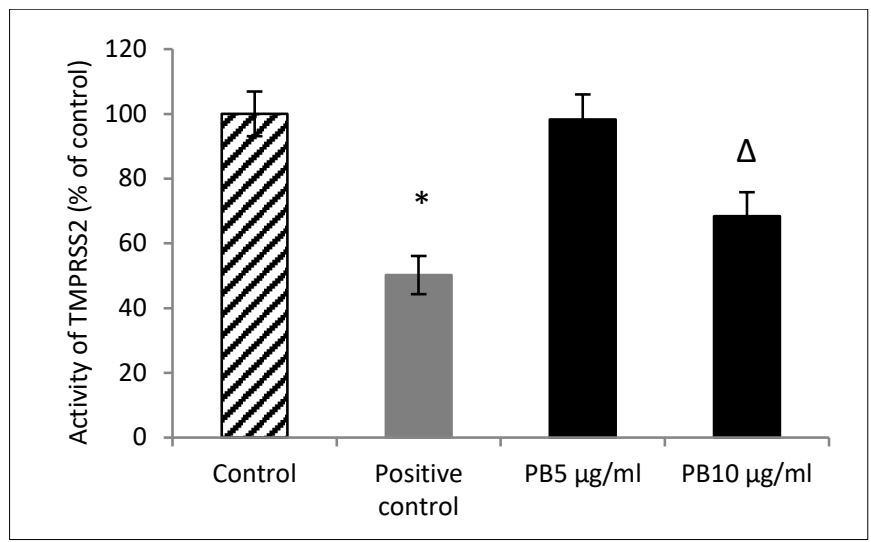

A
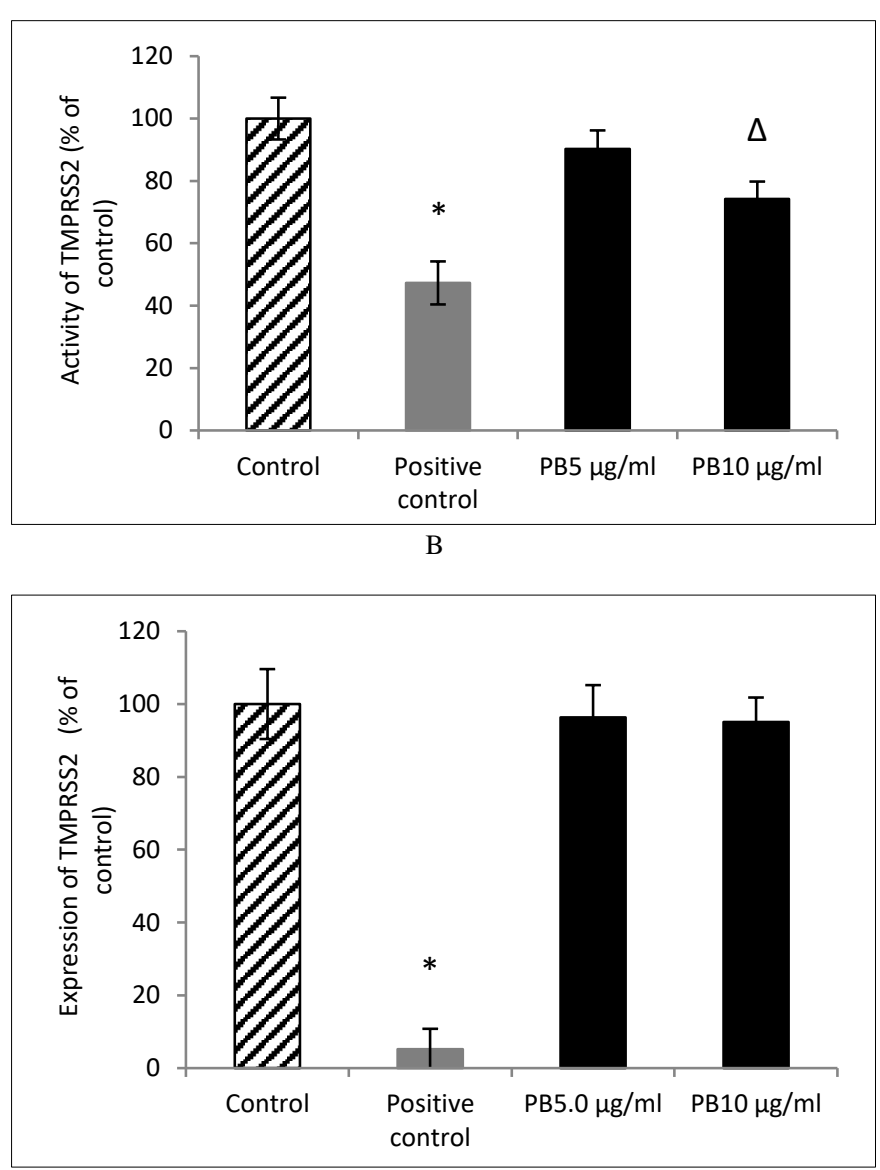

Fig. 4. Effect of PB on TMPRSS2. (A). Activity of recombinant TMPRSS2 upon treatment with PB. $1 \mu \mathrm{M}$ of TMPRSS2 was incubated with PB at indicated concentrations for $1 \mathrm{~h}$ at RT followed by the application of $10 \mu \mathrm{M}$ of fluorogenic substrate for 30 minutes. Fluorescence was recorded at extension/emission $=360 / 440 \mathrm{~nm}$ with a spectrofluorometer. (B). Activity of cellular TMPRSS2 upon treatment with PB. hTMPTSS2/A549 cells were treated with $\mathrm{PB}$ at designated concentrations for $3 \mathrm{~h}$ and $48 \mathrm{~h}$ at $37{ }^{\circ} \mathrm{C}$ and activity was assessed by adding of $200 \mu \mathrm{M}$ fluorogenic substrate and incubation for 30 minutes at $37{ }^{\circ} \mathrm{C}$. Fluorescence was recorded at extension/emission=360/440 nm with spectrofluorometer. (C). Expression of TMPRSS2 in A549 cells after 48h treatment with indicated concentrations of PB assayed by ELISA as described in Experimental Procedures section. Control - 0.01\% DMSO, positive control - 50-100 $\mu \mathrm{M}$ camostat mesylate (enzymatic assays) or dead cells (ELISA assay),

$\Delta \mathrm{p} \leq 0.01, * \mathrm{p} \leq 0.001$.

The effects of $\mathrm{PB}$ on furin activity and its cellular expression are presented in Fig. 5. We observed inhibition of the activity of furin in a cell-free assay with $\mathrm{PB}$ applied between 2.5 and $10 \mu \mathrm{g} / \mathrm{ml}$. However, PB did not inhibit cellular expression of furin at non-toxic concentrations (i.e., up to $20 \mu \mathrm{g} / \mathrm{ml})$.

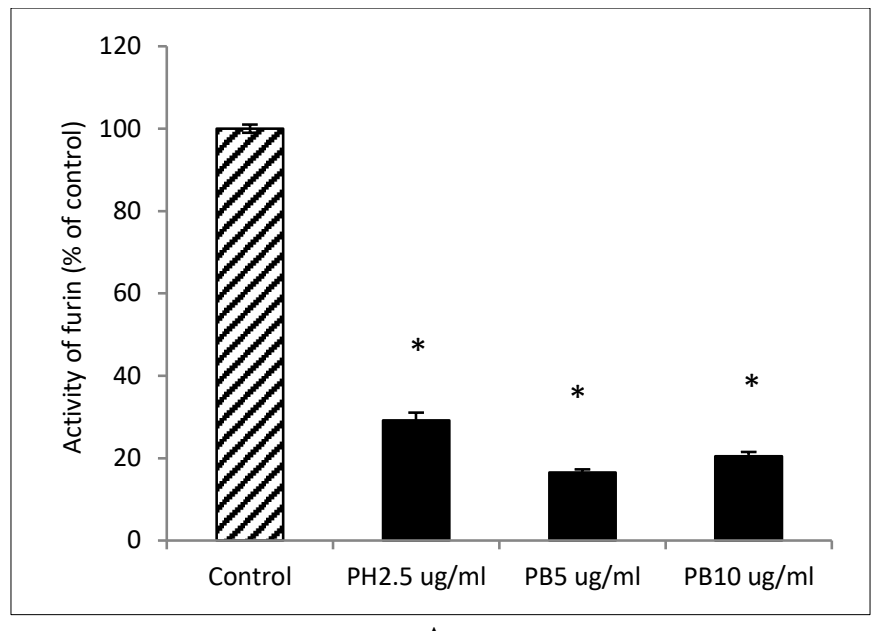

A

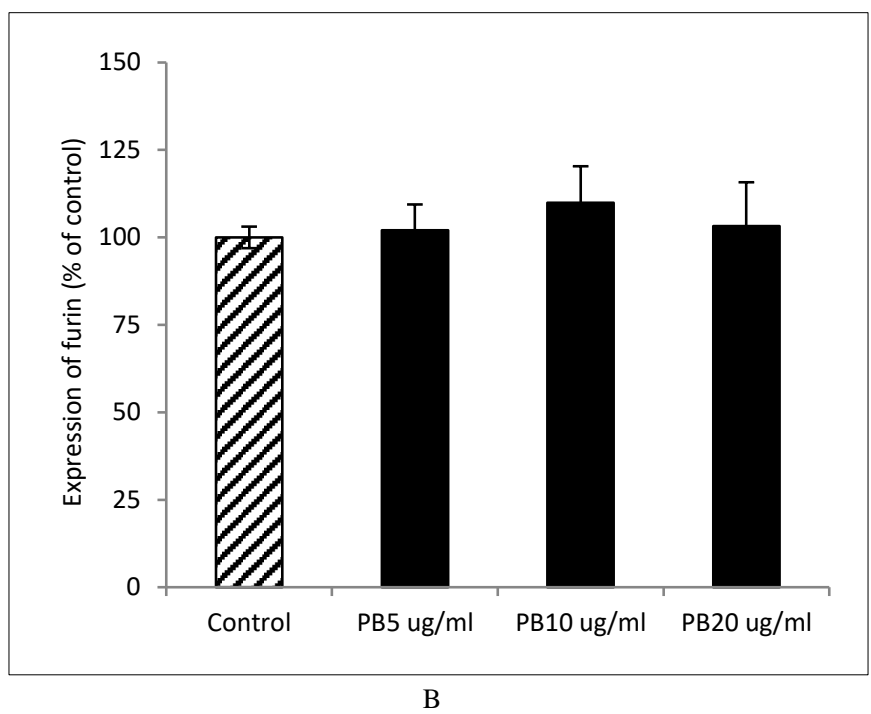

Fig. 5. Effect of PB on furin. (A). Activity of recombinant furin upon treatment with $\mathrm{PB}$. Furin as a recombinant protein was incubated with $\mathrm{PB}$ at indicated concentrations for 15 minutes followed by addition of fluorogenic Rh110 furin substrate, and incubation for $1 \mathrm{~h}$ at $22^{\circ} \mathrm{C}$. The fluorescence was recorded at extension/emission $=490 / 520 \mathrm{~nm}$ with a spectrofluorometer. (B). Expression of cellular furin upon treatment with PB. Furin expression was analyzed in A549 cells by immunochemical ELISA assay using rabbit polyclonal anti-human furin primary antibodies and goat anti-rabbit $\operatorname{IgG}$ polyclonal secondary antibodies conjugated with horseradish peroxidase as described in Experimental Procedures section. Data are expressed as \% of control $\pm \mathrm{SD}$. Control $-0.01 \%$ DMSO,

$* \mathrm{p} \leq 0.001$.

In addition, we tested the effects of $\mathrm{PB}$ on the activity of cathepsin L involved in SARS-CoV-2 endosomal egress in both cell-free and cell-based assay. As shown in Fig. 6 the enzymatic activity of cathepsin L in cell-free assay was reduced by PB in a dose-dependent fashion by $20 \%$ and by $30 \%$ at 5.0 and $10 \mu \mathrm{g} / \mathrm{ml}$ concentrations, respectively. Cathepsin L activity tested in A549 cells was lower by $22 \%$ and $37 \%$ upon treatment with 5.0 and $10 \mu \mathrm{g} / \mathrm{ml}$ concentrations, respectively. Cathepsin $\mathrm{L}$ expression at protein level was not affected by PB at these concentrations (Fig. 6C). 


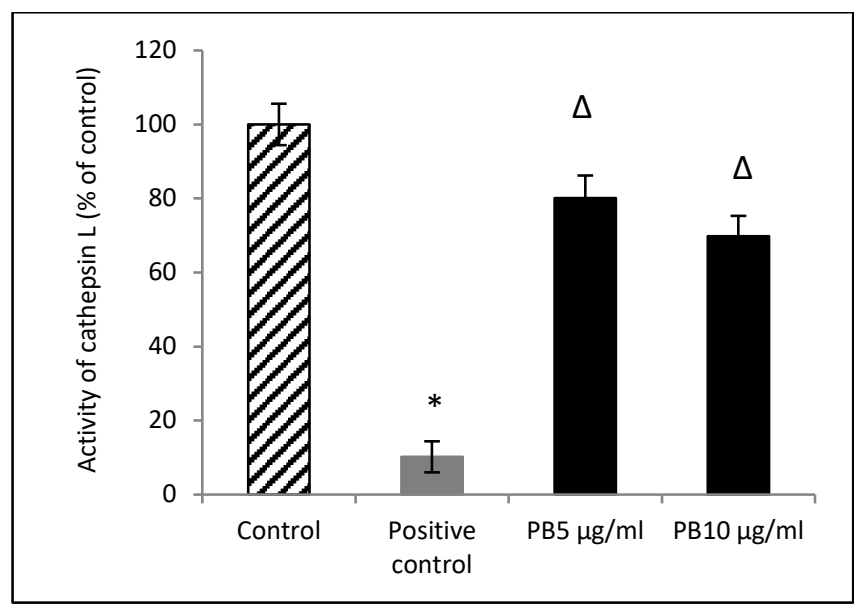

A

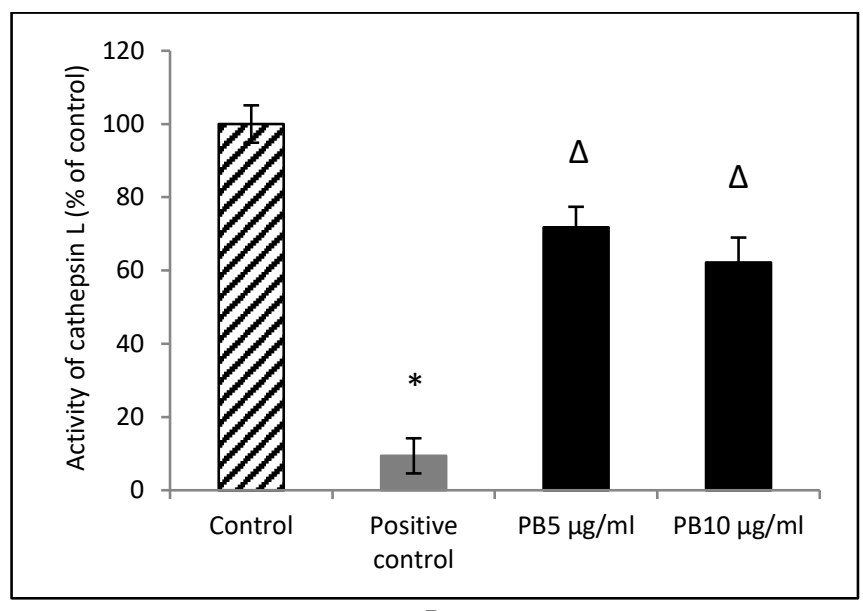

B

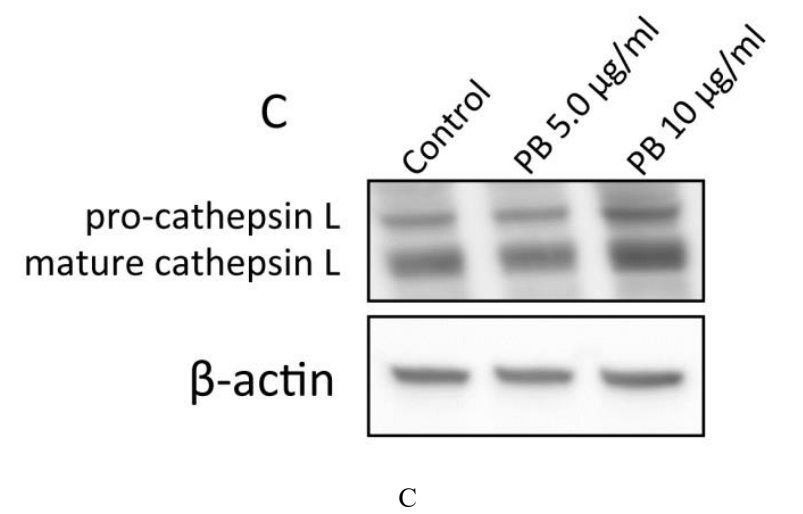

Fig. 6. Effect of PB on cathepsin L. (A). Activity of recombinant cathepsin $\mathrm{L}$ upon treatment with $\mathrm{PB}$. Cathepsin $\mathrm{L}$ at $20 \mathrm{pg} / \mu \mathrm{l}$ was incubated with $\mathrm{PB}$ at indicated concentrations for $1 \mathrm{~h}$ at $22^{\circ} \mathrm{C}$ followed by the application of $10 \mu \mathrm{M}$ of fluorogenic substrate for 30 minutes. Fluorescence was recorded at extension/emission=360/440 nm with a spectrofluorometer. (B). Activity of cellular cathepsin L upon treatment with PB. A549 cells were treated with $\mathrm{PB}$ at indicated concentrations for $24 \mathrm{~h}$ at $37^{\circ} \mathrm{C}$, and activity was assessed by application of $200 \mu \mathrm{M}$ fluorogenic substrate before incubation for 30 minutes at $37^{\circ} \mathrm{C}$. Fluorescence was recorded at extension/emission $=360 / 535 \mathrm{~nm}$ with a spectrofluorometer. (C). Expression of cathepsin L in A549 cells after $48 \mathrm{~h}$ treatment with indicated concentrations of PB assayed by Western blot as described in Experimental Procedures section. Control - 0.01\% DMSO, positive control - $0.1 \mu \mathrm{M}$ E-64; $\Delta \mathrm{p} \leq 0.01, * \mathrm{p} \leq 0.001$.

\section{Effect of $P B$ on viral RNA polymerase}

In our study we also tested whether PB acts beyond the entry steps of the SARS-CoV-2 infection process, by examining whether PB at non-toxic concentrations (i.e., up to $20 \mu \mathrm{g} / \mathrm{ml}$ ) can inhibit the activity of recombinant RdRp. As presented in Fig. 7, PB's inhibitory effect on a SARS-CoV-2 RdRp was dose-dependent with $\sim 15 \%$ statistically significant inhibition achieved at $5.0 \mu \mathrm{g} / \mathrm{ml}$ and $\sim 49 \%$ at $10 \mu \mathrm{g} / \mathrm{ml}$. Moreover, PB used at $100 \mu \mathrm{g} / \mathrm{ml}$ concentration inhibited RdRp activity by nearly $100 \%$.

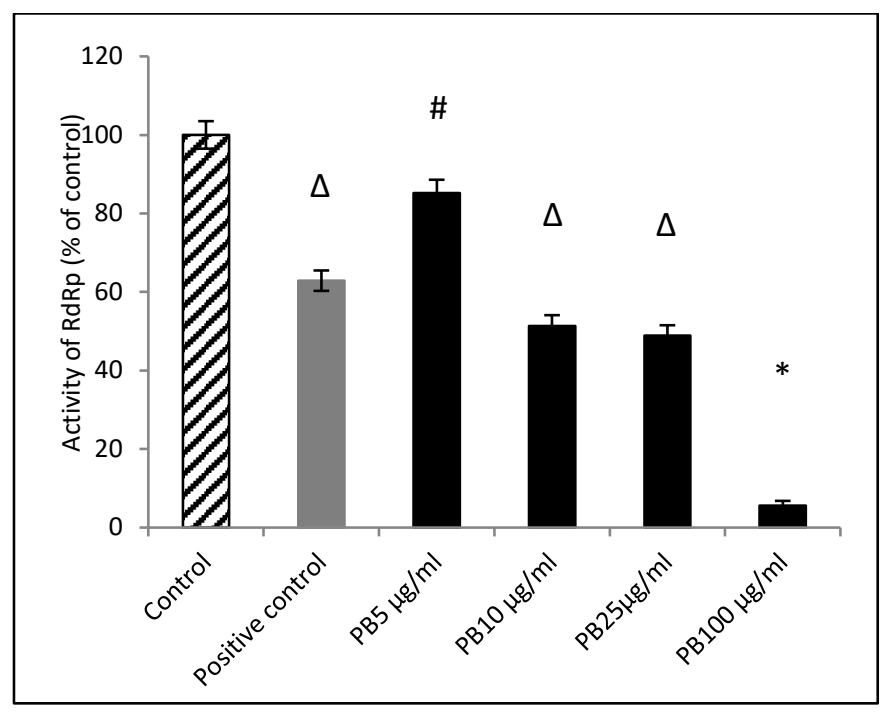

Fig. 7. Effect of PB on viral RdRp. Activity of SARS-CoV-2 RdRp upon treatment with $\mathrm{PB}$ at indicated concentrations. Purified RdRp enzyme was incubated with $\mathrm{PB}$ at designated concentrations for 15 minutes at RT, and subsequent application of reaction mix composed of NTPs and RNA template and further incubation for $2 \mathrm{~h}$ at $34^{\circ} \mathrm{C}$. After adding of fluorescence day signal was measured within $10 \mathrm{~min}$ at extension/emission=488/535 nm with spectrofluorometer. Control $-0.01 \%$ DMSO, positive control $100 \mu \mathrm{g} / \mathrm{ml}$ remdesivir; $\# \mathrm{p} \leq 0.05, \Delta \mathrm{p} \leq 0.01$,

$* \mathrm{p} \leq 0.001$.

\section{DISCUSSION}

The results presented in this study show that a defined combination of active plant components and extracts (PB) can simultaneously affect main cellular steps involved in SARS-CoV-2 infection: its attachment to the ACE2 cellular receptor, and the activity of the key identified enzymes required for cellular entry and replication. These enzymes include TMPRSS2, furin, cathepsin L and RdRp. Our present findings complement our earlier study results with $\mathrm{PB}$, which showed almost $90 \%$ inhibition of the expression of hACE2 on SAEC, thereby reducing the "entry points" for SARS$\mathrm{CoV}-2$ virus, and the inhibition of RBD sequence binding to ACE2 by $87 \%$ [20].

In our study we applied different experimental patterns in order to distinguish the PB effects on SARS-CoV-2 virion before it interacts with the cells, added simultaneously, and after the cells were exposed to the SARS-CoV-2 pseudovirions. In short term study, we observed that inhibitory effect of $\mathrm{PB}$ on virion binding was similar when added at $100 \mu \mathrm{g} / \mathrm{ml}$ concentrations to the viral particles 1 hour before cell inoculations, simultaneously, and 1 hour after cell inoculation with the virions. However, at lower PB concentrations (i.e., up to $25 \mu \mathrm{g} / \mathrm{ml}$ ), the highest and longer-lasting inhibition of viral particles binding to A549 cells was observed when virions were exposed to the PB for 1 hour before interacting with the cells. This would suggest direct interaction of the micronutrients with the viral particles, resulting in the inhibition of viral attachment to human cells. This observation was corroborated by the fact that we did not see 
any effects of $\mathrm{PB}$ on modulating $\mathrm{ACE} 2$ receptor binding properties and ACE2 enzymatic activity.

While PB had no effect on the activity of the ACE2, it merits particular attention in the light of the fact that $\mathrm{PB}$ significantly inhibits the cellular expression of ACE2 in SAEC [20]. We interpret these observations as a function of a regulatory role of $\mathrm{PB}$ in cellular metabolism: while significantly reducing the expression of ACE2 receptors to a low physiological level, thereby limiting infectivity, PB does not affect the activity of these physiologically expressed ACE2 receptors. Such a regulatory effect of $P B$ would be of particular significance, since ACE2 receptors have beneficial effects, e.g., in securing optimum cardiovascular function.

Most of the viruses use host enzymes for the proteolytic processing and maturation of their own proteins. It has been shown that, in addition to using the ACE2 receptor, SARSCoV-2 virus implore NPR-1 molecule that shown dosedependent cellular down-regulation upon treatment with PB as well as that its spike protein depends on proteolytic cleavage at the site between S1 and S2 and on S2 subunit to enable the fusion with and enter the target cell. Hence, the fusion capability of the $\mathrm{CoV}$ is a principal factor of their infection process. Among the proteolytic enzymes involved in the cleavage of spike protein, the TMPRSS2 activity has been shown to be vital for pathogenicity of SARS-CoV-2, accompanied by other enzymes such as cathepsins L [23][25]. Furin is yet another protease involved in cleavage of mammalian, viral, and bacterial substrates [26]. It has been shown that furin action towards the SARS-CoV spike protein is necessary for fusion of virions with host membranes without directly affecting viral infectivity [27]. It appears that effective control and treatment of COVID-19 might necessitate parallel inhibition of several proteases to effectively obstruct these pathological conversions.

Here we have shown that, in addition to impairing viral binding to hACE2 overexpressing cells, the PB downregulated activity of key membrane proteases TMPRSS2, furin, and endosomal cathepsin L. In both cell-free and cellbased assays the reduction of the activity of TMPRSS 2 and cathepsin L by PB was observed at its non-toxic concentrations. Furin activity, too, was significantly reduced at these relatively low PB concentrations. This effect is significant, as the lack of the additional furin cleavage site on the SARS-CoV spike protein has a substantial influence on its infectivity [28]. In addition to SARS-CoV-2 infection, the potential signal link between spike protein, furin, and ACE2 has been implied in the occurrence of adverse cardiovascular events [29]. Finally, we also recorded inhibited activity of $\mathrm{RdRp}$ at these concentrations, which would help to further explain a decreased transduction rate, even after applied spinfection.

Based on this study and our earlier findings [20], this combination of plant-derived compounds and plant extracts may constitute a new therapeutic strategy by simultaneously affecting viral entry, RdRp activity and ACE2 expression. Such a comprehensive effects of naturally occurring compounds on several mechanisms associated with viral infectivity is not surprising. This strategy was also implemented in our earlier studies, including those of human influenza H1N1, bird flu H1N5, and others, which were based on selecting natural components that simultaneously affect key pathology mechanisms across a wide spectrum of infective agents [30]-[33].

This study showed that definite combination of plantderived, biologically active compounds can effectively in simultaneous manner control important steps of the SARSCoV-2 infectivity. Taken together, with the recently established clinical evidence that vitamin $\mathrm{C}$ infusions can successfully combat COVID-19 even at advanced stages, phyto-compounds could represent a relevant approach against SARS-CoV-2 infection.

\section{ACKNOWLEDGMENT}

The authors thank Waldemar Sumera and Rose Schweizer for valued contribution added to this script.

\section{CONFLICT OF INTEREST}

Authors do not have conflict of interest to declare.

\section{REFERENCES}

[1] I. Chakraborty, P. Maity, "COVID-19 outbreak: Migration, effects on society, global environment and prevention." Sci. Total Environ, vol. 728, 138882, 2020.

[2] WHO Coronavirus Disease (COVID-19) Dashboard. Available: https://covid19.who.int/ 2020/11/9.

[3] F. Li. "Structure, Function, and Evolution of Coronavirus Spike Proteins." Annu. Rev. Virol., vol. 3, pp. 237-261, 2016.

[4] N. Zhu, D. Zhang, W. Wang, X. Li, B. Yang, J. Song, et al. "China Novel Coronavirus Investigating and Research Team. A Novel Coronavirus from Patients with Pneumonia in China 2019.” N. Engl. J. Med., vol. 382, pp. 727-733, 2020.

[5] W. Li, M. J. Moore, N. Vasilieva, J. Sui, S. K. Wong, M. A. Berne, et al. "Angiotensin-converting enzyme 2 is a functional receptor for the SARS coronavirus," Nature, vol. 426, pp. 450-454, 2003.

[6] H. Hoffmann, K. Pyrc, L. van der Hoek, M. Geier, B. Berkhout, S Pohlmann, et al. "Human coronavirus NL63 employs the severe acute respiratory syndrome coronavirus receptor for cellular entry." Proc. Natl. Acad. Sci. USA, vol. 102, pp. 7988-7993, 2005.

[7] L. Du, Y. He, Y. Zhou, S. Liu, B. J. Zheng, S. Jiang, et al. "The spike protein of SARS-CoV - a target for vaccine and therapeutic development." Nat. Rev. Microbiol, vol. 7, pp. 226-236, 2009.

[8] L. Du, Y. Yang, Y. Zhou, L. Lu, F. Li., S. Jiang, et al. "MERS-CoV spike protein: a key target for antivirals." Expert. Opin. Ther. Targets, vol. 21, pp. 131-143., 2017.

[9] L. Cantuti-Castelvetri, R. Ojha, L. D. Pedro, M. Djannatian, J. Franz, S. Kuivanen, et al. "Neuropilin-1 facilitates SARS-CoV-2 cell entry and infectivity." Science, vol. 370, pp. 856-860, 2020.

[10] J. L. Daly, B. Simonetti, K. Klein, K. E. Chen, M. K. Williamson, C. Anton-Plagaro, et al. "Neuropilin-1 is a host factor for SARS-CoV-2 infection.” Science, vol. 370, pp. 861-865, 2020.

[11] X. Ou, Y. Liu, X. Lei, P. Li, D. Mi, L. Ren, et al. "Characterization of spike glycoprotein of SARS-CoV-2 on virus entry and its immune cross-reactivity with SARS-CoV." Nat. Commun., vol. 11, pp. 1620, 2020.

[12] M. Hoffmann, H. Kleine-Weber, S. Schroeder, N. Krüger, T. Herrler, S. Erichsen, et al. "SARS-CoV-2 Cell Entry Depends on ACE2 and TMPRSS2 and Is Blocked by a Clinically Proven Protease Inhibitor.' Cell, vol. 16, no. 181, pp. 271-280, 2020.

[13] J. A. Jaimes, N. M. André, J. S. Chappie, K. Jean, and J. K. Millet "Phylogenetic Analysis and Structural Modeling of SARS-CoV-2 Spike Protein Reveals an Evolutionary Distinct and Proteolytically Sensitive Activation Loop." J. Mol. Biol. vol. 432, no. 10, pp. 33093325,2020 .

[14] B. J. Bosch, R. van der Zee, C. A. de Haan, and P. J. Rottier. "The coronavirus spike protein is a class I virus fusion protein: structural and functional characterization of the fusion core complex." J. Virol. vol. 77, no. 16, pp. 8801-8811, 2003.

[15] A. R. Fehr, and S. Perlman. "Coronaviruses: an overview of their replication and pathogenesis." Methods Mol. Biol. vol. 1282, pp. 1-23, 2015 . 
[16] J. Zhang, X. Rao, Y. Li, Y. Zhu, F. Liu, G. Guo, et al. "High dose vitamin C infusion for the treatment of critically ill COVID-19." Ann Intensive Care, vol. 11, no. 1, pp. 5, 2021.

[17] V. K. Bhardwaj, R. Singh, J. Sharma, V. Rajendran, R. Purohit, and S. Kumar. "Identification of bioactive molecules from tea plant as SARSCoV-2 main protease inhibitors." J Biomol Struct Dyn, vol.39, no. 10, pp. 3449-3458, 2021.

[18] A. Andreou, S. Trantza, D. Filippou, N. Sipsas, S. Tsiodras. "COVID19: The Potential Role of Copper and N-acetylcysteine (NAC) in a Combination of Candidate Antiviral Treatments Against SARS-CoV2." In vivo 34, suppl. 3, 1567-1588, 2020.

[19] L. Chen, C. Hu, M. Hood, X. Zhang, L. Zhang, J. Kan, et al. "A Novel Combination of Vitamin C, Curcumin and Glycyrrhizic Acid Potentially Regulates Immune and Inflammatory Response Associated with Coronavirus Infections: A Perspective from System Biology Analysis." Nutrients, vol. 12, no. 4, pp. 1193, 2020.

[20] V. Ivanov, S. Ivanova, A. Niedzwiecki, and M. Rath. (January 2021). "Effective and safe global public health strategy to fight the COVID19 pandemic: Specific micronutrient combination inhibits Coronavirus cell-entry receptor (ACE2) expression." J. Cell. Med. \& Nat. Health. [Online].

Available:https://jcmnh.org/index.php/2020/07/02/effective-and-safeglobal-public-health-strategy-to-fight-the-covid-19-pandemicspecific-micronutrient-composition-inhibits-coronavirus-cell-entryreceptor-ace2-expression/.

[21] A. Goc, W. Sumera, V. Ivanov, A. Niedzwiecki, and M. Rath, M. (August 2020) "Micronutrient combination inhibits two key steps of coronavirus (SARS-CoV-2) infection: viral binding to ACE2 receptor and its cellular expression." J. Cell. Med. \& Nat. Health. [Online].

Available:https://jcmnh.org/index.php/2020/08/14/micronutrientcombination-inhibits-two-key-steps-of-coronavirus-sars-cov-2infection-viral-binding-to-ace2-receptor-and-its-cellular-expression/.

[22] R. Pászti-Gere, R. Czimmermann, G. Ujhelyi, P. Balla, A. Maiwald, and T. Steinmetzer. (2016) "In vitro characterization of TMPRSS2 inhibition in IPEC-J2 cells." J. Enzyme Inhib. Med. Chem., vol. 31, suppl. 9, pp. 123-129, 2016.

[23] I. Glowacka, S. Bertram, M. A. Müller, P. Allen, E. Soilleux., S. Pfefferle, et al. (2011) "Evidence that TMPRSS2 activates the severe acute respiratory syndrome coronavirus spike protein for membrane fusion and reduces viral control by the humoral immune response," $J$. Virol. vol. 85, no. 9, pp. 4122-4134, 2011.

[24] Iwata-Yoshikawa, N., Okamura, T., Shimizu, Y., Hasegawa, H., Takeda, M., et al. (2019) "TMPRSS2 Contributes to Virus Spread and Immunopathology in the Airways of Murine Models after Coronavirus Infection." J. Virol. 93, 01815-01818.

[25] T. Liu, S. Luo, P. Libby, and G. P. Shi. "Cathepsin L-selective inhibitors: A potentially promising treatment for COVID-19 patients." Pharmacol. Ther. Vol. 213, pp. 107587, 2011.

[26] S. Tian, Q. Huang, Y. Fang, J. Wu. "Furin DB: A database of 20residue furin cleavage site motifs, substrates and their associated drugs." Int. J. Mol. Sci., vol. 12, no. 2. pp. 1060-1065, 2011.

[27] K. E. Follis, J. York, J. H. Nunberg. "Furin cleavage of the SARS coronavirus spike glycoprotein enhances cell-cell fusion but does not affect virion entry." Virology, vol. 350, no. 2, pp. 358-369. 2006.

[28] B. A. Johnson, X. Xie, B. K. Kumari, G. Lokugamage, A. Muruato, A., J. Zou, et al. (2020) "Furin Cleavage Site Is Key to SARS-CoV-2 Pathogenesis." bioRxiv, [Preprint], Aug 26:2020.08.26.268854, 2020.

[29] Y. Ming, and L. Qiang. "Involvement of Spike Protein, Furin, and ACE2 in SARS-CoV-2-Related Cardiovascular Complications." $S N$ Compr. Clin. Med. [Online ahead of print] vol. 11, 1-6, 2020.

[30] E. K. Barbour, E. G. Rayya, A. S. Houssam, R. G. El-Hakim, A Niedzwiecki, et al. "Alleviation of Histopathologic Effects of Avian Influenza Virus by a Specific Nutrient Synergy." Int. J. Appl. Res. Vet. Med. vol. 5, pp. 9-16, 2007.

[31] P. G. Deryabin, D. K. Lvov, A. G. Botikov, V. Ivanov, T. Kalinovsky, A. Niedzwiecki, et al. "Effects of a nutrient mixture on infectious properties of the highly pathogenic strain of avian influenza virus A/H5N1." BioFactors, vol. 33, no. 2, pp. 85-97, 2008.

[32] R. J. Jariwalla, M. W. Roomi, B. Gangapurkar, T. Kalinovsky, A. Niedzwiecki., M. Rath, "Suppression of influenza A virus nuclear antigen production and neuraminidase activity by a nutrient mixture containing ascorbic acid, green tea extract and amino acids." BioFactors, vol. 31, no. 1, pp 1-15, 2007.

[33] R. J. Jariwalla, B. Gangapurkar, A. Pandit, T. Kalinovsky, A. Niedzwiecki, and M. Rath, "Micronutrient Cooperation in Suppression of HIV Production in Chronically and Latently Infected Cells." Mol. Med. Rep. vol. 3, no. 3, pp. 377-385, 2010. 